\title{
Mentions of music in the Antarctic diaries of Cecil T Madigan ${ }^{1}$
}

\author{
Arnan Wiesel
}

Dr Cecil Thomas Madigan (Figure 1) was the meteorologist on Douglas Mawson's Australasian Antarctic Expedition. He led the eastern sledging party, and was also leader of the group of men who stayed behind in February 1913 when Mawson's party failed to return to their base at Commonwealth Bay in time to return to Australia on the relief ship. His expedition diaries were published in $2012 .^{2}$

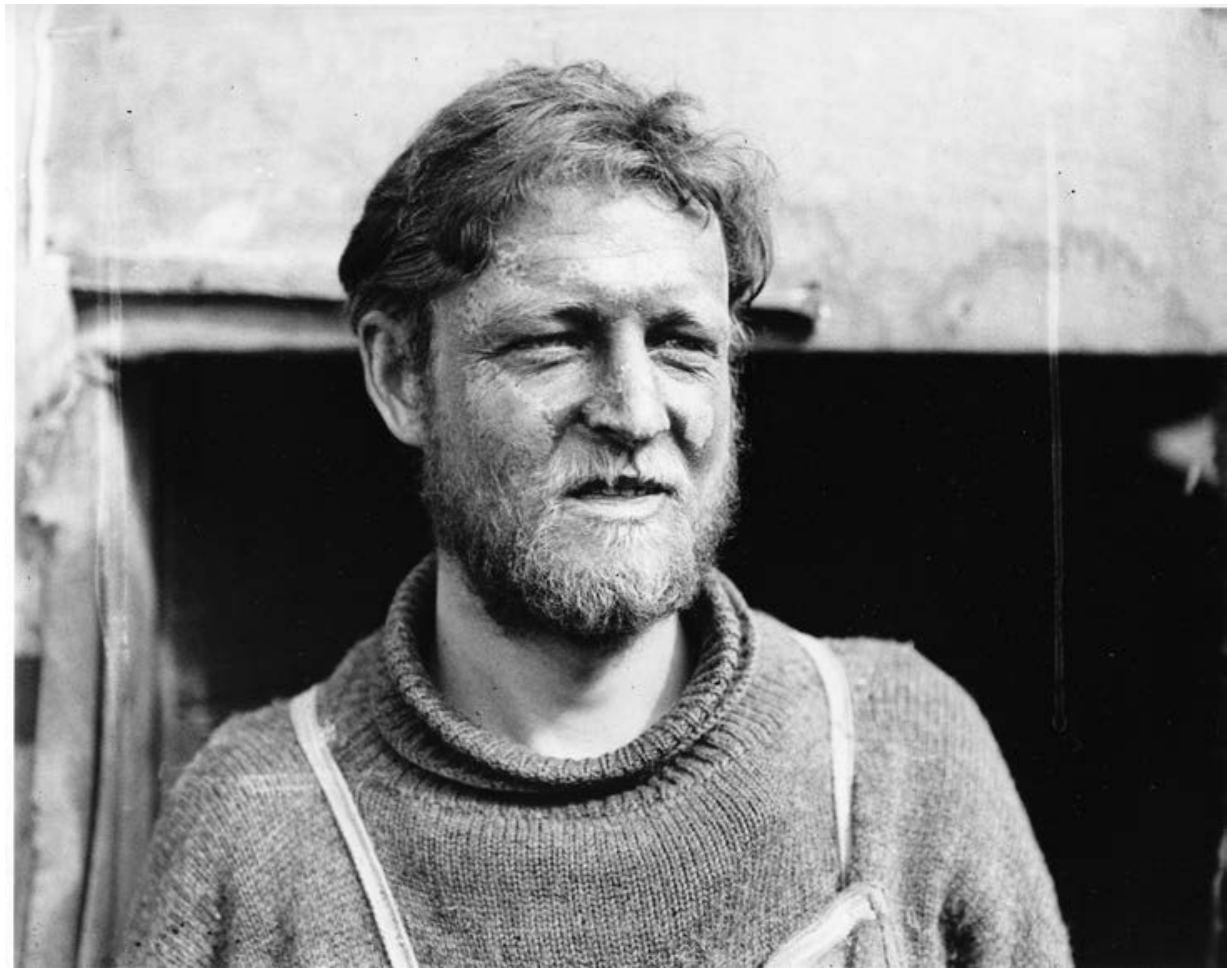

Figure 1. Cecil Thomas Madigan, ca 1912.

Source: Photo by Frank Hurley, courtesy National Library of Australia.

\footnotetext{
1 Mr Arnan Wiesel, pianist and former Head of Keyboard, ANU School of Music.

2 CT Madigan's complete diaries, held in a family archive, were published in 2012: CT Madigan (2012) Madigan's account: the Mawson expedition - the Antarctic diaries of CT Madigan, 1911-1914, transcribed by JW Madigan. Wellington Bridge Press, North Hobart.
} 
The mentions of music in his diaries during Australasian Antarctic Expedition of 1911-14 show that musical activities were a vital part of daily life in the isolated and harsh environment. He mentions musical events as well as music listening sessions. These were part of an extensive creative range of social activities that included, for example, staging plays and poetry competitions.

'We have arranged Wed \& Sunday as singing night', wrote Madigan on 3 April 1912. Singing activities included both secular and religious songs. It is important to differentiate between the two streams of musical styles, as each addressed very different social needs. Hymns and other religious singing gave a needed sense of security and connection with faraway home. One gets an idea of the comforting feeling, clearly articulated by Madigan:

I am very fond of Oh Lord \& Father of mankind to a tune called Rest - it has memories ...

The contralto Abide with me is beautiful - I must have that sung to me by an alto I know when I get back again to bonny S.A.

The hymns always put me in a sentimental mood - I think of home and of 'Raywood'. How I long for those quiet evenings round the little organ at 'Raywood'. ${ }^{3}$

The hymns also had strong connotations of the British Empire. Australians are rightly very proud of the first Australian-led expedition to Antarctica, but the unmistakable colonial flavour of the music mentioned open for us a window to the real cultural heritage of the expedition. The secular music might have been more Australian in character, but the hymns represented the tradition of Empire.

Madigan mentions many, and noted that:

We use the Congregational hymn book which I admit is better than ours. (Hymns Ancient and Modern - the Anglican hymn book) ... Stillwell is a Congregationalist and knows their hymns very well \& the good tunes. ${ }^{4}$

Frank Stillwell was the men's organist during services.

Even in the secular music we see the strong connection with Britain. Two of the three specific performers Madigan mentioned in his diaries during the first year give us a glimpse of popular listening of the time.

Dame Clara Butt (1872-1936) was a well-known English contralto singer whom Madigan mentions being played as part of a Sunday evening sacred music at

3 CT Madigan diaries, 21 July 1912. 'Raywood' was the name of the Adelaide home of Madigan's fiancée.

4 CT Madigan diaries, 19 May 1912. 
the Commonwealth Bay hut, together with the British Army's Coldstream Choir. Dame Clara was a symbol of the British Empire in stature (she was more than 6 feet tall) and through her extroverted and majestic performances. During the years before the expedition she was at the height of her popularity, and was renowned for her renditions of hymns and traditional English tunes.

The second popular performer, Harry Lauder (1870-1950), was a Scottish entertainer. His contribution to the listening repertoire of the expeditioners was more with the entertainment aspect of music. As a contrast to the more traditional and secure world of hymns, the light entertainment character of Lauder's music would have perhaps fuelled the fun, creative activities of the men over the two years.

Madigan mentions of a third figure, Chapman Alexander, as part of an evening of hymns, probably reflects the influence of two evangelical trips to Australia by the American preacher Charles Alexander. Alexander (1867-1920) joined forces with John Chapman (1859-1918) and the hymns sung in these large-scale events were a vital part of the bonding process. 


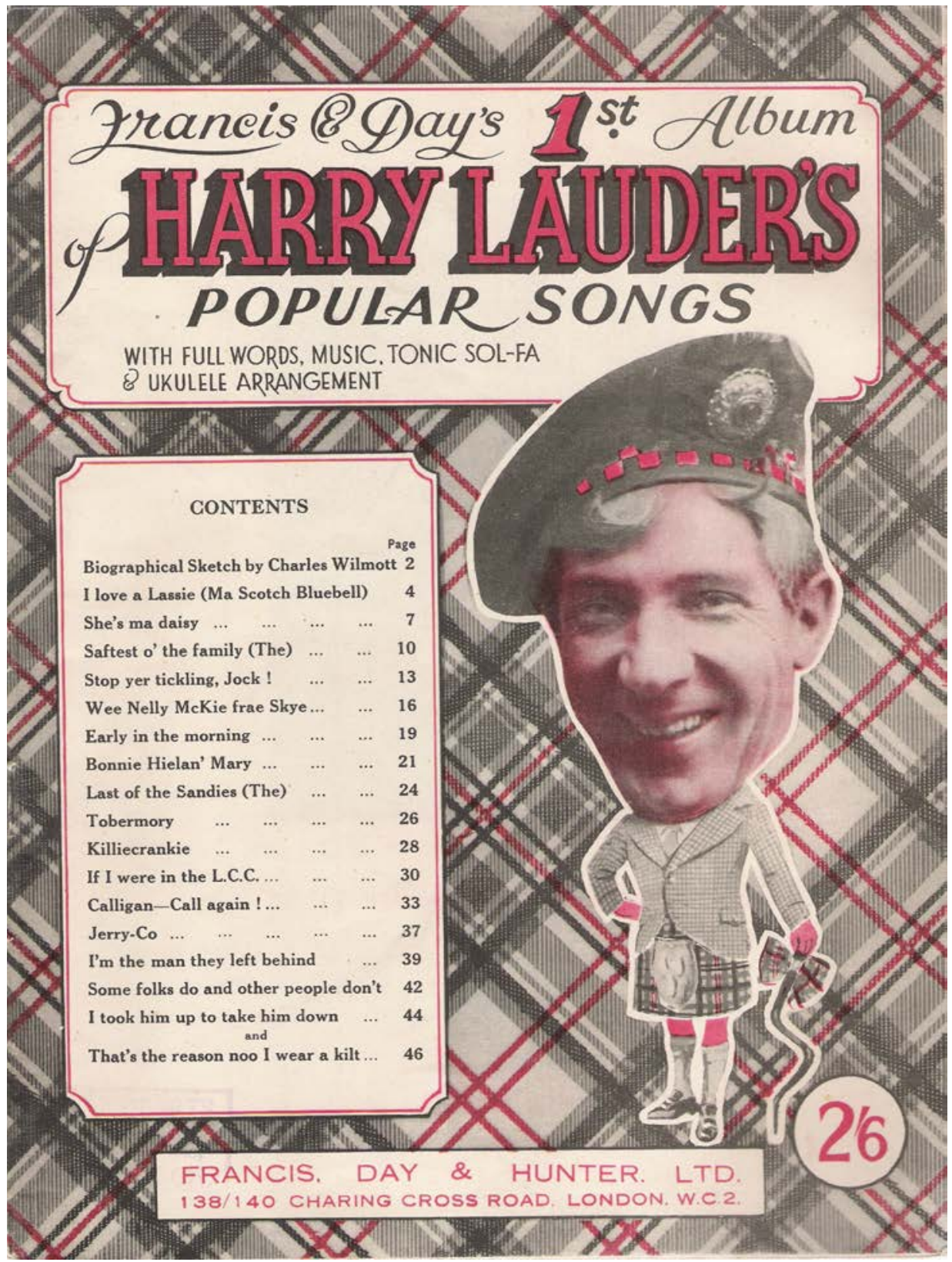

Figure 2. Harry Lauder popular song book, published by Francis Day in 1905.

Source: Wikipedia, The Free Encyclopedia, http://en.wikipedia.org/w/index.php?title=Harry_ Lauder\&oldid $=636746009$. 
The Chapman Alexander Simultaneous Campaign of large-scale evangelical events started in 1908 in Philadelphia, USA, and included a visit to Australia in 1909, with a month each in Melbourne and Sydney, two weeks in Brisbane and ten days in Adelaide, as well as shorter visits to Albury, Ballarat, Bendigo, Castlemaine, Moss Vale and Townsville. It is important to note the men's services involved with these events in relation to the all-male social reality at the Mawson Hut.

Although the expedition is acknowledged as the first Australian expedition to Antarctica, interestingly, the international character of the expedition was evident in the language used in musical performances. Madigan records that songs the men sang included Ich bin der Doctor Eisenbahn,Liebes Schätzeken, La Marseillaise and Treue Liebe. Music is always an important indicator of the character and origins of people. The Swiss mountaineer Xavier Mertz contributed an international flavour to the expedition and Madigan, who had some knowledge of German, put this to use in the musical events.

Many of the expeditioners had recently finished university, so it is no wonder at Madigan's mention of various student songbooks - the Varsity Boat Songs, Scottish Students' Song Book, The Australasian Students' Song Book, and The Globe Song Folio. Madigan was to go to Oxford upon his return from the expedition and participate in the rowing program, so the 'varsity (university) boat songs would have had an important link to the future.

The more actively engaging musical activities show a great deal of creativity. As the Adelie Blizzard, produced in the expedition's second year at the hut (the expedition newspaper), also shows, these activities combined with plays and other events contained a great deal of humour. 'Hurley as usual was the funniest - he had the gramophone horn and a length of rubber hose which he wound over his shoulder — his bass notes were a leading feature'.

The use of elements such as the Morse code in whistles gives another glimpse of the creative ideas the expeditioners came up with. A comment such as, 'We worked up in pitch at the rate of about an octave per verse \& had several changes of key to get it down again' shows a healthy sense of not taking oneself too seriously.

5 Friends of the State Library of South Australia (2010) The Adelie Blizzard: Mawson's forgotten newspaper, 1913, Friends of the State Library of South Australia in association with the Friends of Mawson at the South Australian Museum, Adelaide. 


\section{Examples of musical activities from Madigan's diaries}

The following passages from Madigan's diaries (transcribed by Julia W Madigan) have been selected by the author, Arnan Wiesel, and Alice Giles.

\section{First year of expedition}

26 November 1911 [Sang] all the good old songs \& also our Varsity boating songs. Mary had a William Goat was not neglected.

2 December 1911 A farewell dinner at Mawson's ${ }^{6}$ expense - sang For he's a jolly good fellow - not 'freeze'.

8 December 1911 [On the boat] we pass the time doing Morse code in whistles ...We left the Larboard Watch to the best singers - it sounded fine in the twilight, with big seas running and the vessel heeling in big slow rolls. Wild ${ }^{7}$ sang Absent and with much feeling ... we also sang Abide with me.

9 December 1911 Chorus - Sweethearts and Wives / Sweethearts \& wives, they are the dearest thing in our lives. / When pretty lips meet / My! What a treat / Oh who cd help loving the darlings!

18 December 1911 After tea all collected round the piano with the Scottish Students' Song Book and had a great old sing song. Nothing cheers one up like a few chorus songs, especially the old ones. Hoadley ${ }^{8}$ is our pianist. Sang some good shanties on the hauling; 'A roving'. Mertz did some 'yodels' and sung German student song to the tune of 'Up-iDee' which made a good chorus.

31 December 1911 Just before tea we had a sing-song, some hymns and the Australian Students' Song Book. It was good to sing the 'Ode to Tobacco' and 'Meerschaum Pipe' and 'Waltzing Matilda' again, not forgetting 'Mary's William Goat'.

30 January 1912 First sit down meal in hut ... Songs were put down [on the menu] as Walzing Matilda by Madigan, Annie Laurie by Hannam ${ }^{9}$ \& Poor Old Joe by Laseron. ${ }^{10}$ The first named has become very popular

\footnotetext{
Douglas ('Doc') Mawson (1882-1958), the expedition leader.

Frank Wild (1873-1939), leader, western base.

Charles Archibald ('Arch') Hoadley (1887-1947), geologist on the Western Party.

Walter Hannam (1885-1965), wireless engineer and mechanic.

Charles Laseron (1887-1959), taxidermist and biological collector.
} 
with adopted Antarctic words ... The Doc got out the gramaphone [sic] - an Edison with the 'His master's voice' pictures on it. We had about a half a dozen records.

2 February 1912 We had the grama going again — some Harry Lauder, band selections, Take a pair of sparkling eyes etc.

11 February 1912 This is a little more like Sunday Evening. The gramophone is in splendid working order and Hurley is putting through some beautiful sacred records. All the dear old hymns - Abide with me, Nearer my God to Thee, Adeste Fidelis - they remind me of home ... We have now just heard Clara Butt \& now comes Christchurch Bells played by Coldstream Guards - finished — it was beautiful.

18 February 1912 I got down the gramophone and went through a few sacred records - Holy City, Abide with me, Nearer my God to Thee, Messiah, Holy Holy Holy, There is a green hill. I love these old hymns. They are all good choirs. I wish we had old Wild here with his singing. He was for some years in the St Paul's Choir, London.

25 February 1912 We sang Near my God to Thee and God our help in Ages past. The little organ was unpacked and Stillwell played it.

3 March 1912 Service again today - it will be regular now. Hymns Lead kindly Light and Eternal Father.

7 March 1912 Played the grama after Caruso's [the dog's] surgical operation was over. Soon I'll be back with the colleen I adore, Eileen Allanah, Argus Asthare.

17 March 1912 Laseron is working the phono - the hymns by the London Mixed Choir are A.1. I love hymns.

22 March 1912 MacLean $^{11}$ on the grama - we have some bonzer pieces Valse Espana, When the sun is sinking, a sweet little coon song, some banjo selections, Sparkling eyes and others.

24 March 1912 After tea we got the little organ going. Stillwell ${ }^{12}$ playing, and sang all the dear old hymns. Hannam has a very good tenor voice, and everyone sings a bit.

27 March 1912 [MacLean's birthday celebration:] then a musical programme to which nearly everyone contributed.

11 Dr Archibald MacLean (Dad) (1885-1922), medical officer.

12 Frank Stillwell (1888-1963), geologist. 
28 March 1912 After dinner I started in to give a phonograph concert - I went through all records and made a selection and then arranged them. It was greatly enjoyed - nearly everyone got into bed and I expect most of them were sung to sleep. I unearthed a new song I had always passed it over on the name I know of two bright eyes but this name belies its character. It is a tenor, soft and musical with beautiful words.

31 March 1912 In the evening Hunter ${ }^{13}$ \& Hurley ${ }^{14}$ sang a parody they had made up on the subject - quite good - tune Yip-I-Addy.

3 April $1912 \quad$ We have arranged Wed \& Sunday as singing night. We went through all the old Scottish Students' Songs tonight \& a lot of the Aust. Uni songs - a good time.

7 April $1912 \quad$ Easter Sunday [For Easter service] we sang Christ the Lord is risen today and another hymn.

It has been the custom for the cook \& messman to sing a song during dinner for some time past. Hurley \& Hunter started it with their original songs. Last night Hannam \& MacLean sang Ye banks and braes. Mertz ${ }^{15}$ was cook today, Hannam messman \& Mertz came to me as I was going to bed and asked me to help him with one. In spite of my fit of the blues I did it - we made one which was supposed to be Basilisk [the dog] singing, with a barking chorus to the tune of Ich bin der Doctor Eisenbahn. I put a lot of Mertz's funny sayings in, which of course he did not appreciate. I thought it very poor. Mertz taught it to Hannam \& they gave it. It was most successful - cries of 'we want more' \& the opinion that it was the best to date. The authorship was unknown \& still is.

Sang hymns tonight after helping wash up. I wish we had old Wild here. $\mathrm{He}$ is a bonzer singer - once in St Paul's Choir.

8 April $1912 \quad$ Murphy ${ }^{16}$ was cook today and Close ${ }^{17}$ messman. We gave them a fearful time at dinner for a song - neither can sing. At last old Close sang Queen of the Earth - it was quite pathetic. I was glad no one laughed, although it was hard not to. We gave him a good cheer.

9 April 1912 We had high jinks at dinner ... then songs \& recitations all round. I fired off my beastly old timer.

13 John Hunter (1888-1964), biologist.

14 Frank Hurley (Hoyle) (1885-1962), photographer.

15 Xavier Mertz (1882-1913), dog-keeper.

16 Herbert Murphy (1879-1971), in charge of stores.

17 John Close (1871-1949), assistant collector. 
14 April 1912 We sang hymns this evening for a long while, starting with Lead kindly Light, Abide with me, Nearer my God and ending with Chapman Alexander. Stillwell plays, and MacLean, Hunter, Laseron, Hannam \& I \& Mawson sing. Mawson is rather sacreligious he wanted Arise oh Christian soldier \& put your burberrys on.

18 April 1912 Had our weekly sing song tonight. Scottish Students, Globe and Aust Students' song books. MacLean sang Afton Water and Hannam My Pretty Jane as solos.

20 April 1912 Mertz sang a song at tea time - Hurley sang Ich bin der Doctor Eisenbard in German — or alleged German, \& Mertz sang his English translation, which he gave me.

21 April 1912 Stillwell, our organist, is night watchman \& having a sleep before coming on duty so we have no hymns. I put all the hymns through on the grama. We have Abide, Holy Holy Holy, Green Hill, Christian Soldiers, Ave Maria, Nearer my God.

26 April $1912 \quad \ldots$ and overall the absolute, almost dreadful, silence. We walked round the peninsula, sitting a while right at the point. We got a fine echo from the islands - Mertz's yodelling sounded well.

28 April 1912 Hymns this evening with Stillwell, MacLean, Hannam \& myself. Stillwell is a Congregationalist and knows their hymns very well \& the good tunes. We had a lot of well known ones.

2 May 1912 I picked out two records then, La Cinquataine, a beautiful harp solo, and Ben The Bos'n, a rousing song, and put them on the gramo in that order as a 'rise \& shine'.

5 May 1912 [Hurley] and Hunter sang 3 songs of their own manufacture which were very funny, mostly jokes at the expense of various members ...

12 May 1912 After dinner we had a great old sing of hymns.

19 May 1912 After dinner helped Bick ${ }^{18}$ who was messman, \& then we had our hymns - the usual four, Laseron, Hannam, MacLean \& I with Stillwell playing. We have a good quartet, with one notable exception. We use the congregational hymn book which I admit is better than ours.

18 Francis Bickerton (Bick) (1889-1954), mechanic. 
7 June 1912 Hymns tonight — Dear Lord and Saviour is becoming popular — I always suggest it.

... and started the gramo: with dreamy waltzes at 7:10, 'rise $\&$ shine' at $7: 45$.

The Adelie Land band got going tonight - there were Corell ${ }^{19}$ with his piccolo, MacLean with Ninnis'20 mouth organ, Ninnis with his concertina, Hunter with an empty carbide tin strapped in front as a kettle drum, Laseron with a comb, Hodgeman ${ }^{21}$ with some suspended lengths of pipe and Mertz with two pot lids as cymbals. It sounded rather fine - they played British Grenadiers, Swannee River, Yip-i-addy, Auld Lang Syne, Stop your ticklin' Jock, etc. Hurley as usual was the funniest - he had the gramaphone horn and a length of rubber hose which he wound over his shoulder - his bass notes were a leading feature.

9 June 1912 Webb $^{22}$ played the organ, but we had no hymns tonight — Bick put our few gramo ones through.

21 June 1912 [Midwinter's Day 1912] I ran the gramo during dinner, which was a great success vide menu ... Then we sang a song Dad had made up ... Laseron sang, also Hannam ... Then the National Anthem and Old Lang Syne.

21 July 1912 After dinner we sang hymns, quite a nice little gathering of Stillwell, McLean, Laseron, Hunter and myself \& Corell. Corell is probably the most musical of us all but he won't sing. He plays the piccolo beautifully, \& accompanys the organ. I suppose old Alec does the same at Wild's base.

30 July 1912 We got the organ down and the Scottish Students' Song Book, Laseron, Hunter, Stillwell \& myself. The old plantation songs always make me think of 'Yunkunger'.

3 August 1912 We have all kinds of records, many beautiful choir hymns. I put on first Onward Christian Soldiers which is a processional hymn starting scarcely audible, then Abide with Me sung in a beautiful alto \& a tune I must get, The Village Blacksmith which is a fine old song in

19 Percy Corell (1892-1974), mechanic and assistant physicist.

20 Belgrave Ninnis (1887-1912), dog-keeper.

21 Alfred Hodgeman (1886-1964), cartographer and sketch artist.

22 Eric Webb (1889-1984), chief magnetician. 
a manly base, a very pretty sentimental song ( $I$ know of two white arms, waiting for me, I know of two red lips, praying for me), Eileen Alannah, Humoresque, a violin solo, Nearer my God Thee etc.

16 August 1912 [Hodgeman's birthday] After dinner Hoyle got out a musical programme, consisting of Cameron Men, and Ye Banks \& Braes by MacLean, Piccolo solos by Little Willeee Smith, My Pretty Jane by Hannam ... A Roving by Hunter \& Hurley, Larboard Watch by Hannam and Laseron ... Liebes Schätzeken and La Marsellaise by Mertz, and Walzing Matilda \& The Good Rhein Wine by myself (compulsory), also selections by the Adelie Band, concluded by Old Folks at Home and Auld Lang Syne by the company.

3 September 1912 [Hurley] has not been so lively of late, but tonight he got back his old form, \& gave us some [negro] songs in his get up, pulling in and out the bellows of his wet camera like a concertina. He amuses me immensely.

8 September 1912 I gave a good selection of hymns before calling the sleepers this morning [Sunday] ... After dinner I gave another gramo concert. Old Dux ipse [Mawson] quite cheered up during it, and told one or two to stop their jobs and have a holiday as it was Sunday night - a thing he has never done before.

6 October 1912 Then cigars went round, \& MacLean sang a comic little French song (Anglo-French style) \& Laseron sang a PidginGerman song he invented, very good, \& Hoyle did one of his dress ups, representing J.C. after the sledging, all bandages \& frost-bites, \& sang a song, with verses about different people, including Mertz ... When this was over, a regular concert set in - Stillwell got down the organ \& most of us sang something. I sang Treue Liebe for Mertz's special benefit. Bage $^{23}$ gave a good Kipling recitation, Laseron, MacLean, Hannam, Hunter sang, Corell gave piccolo solos (very good) \& we had several choruses. It was a most enjoyable evening \& bucked us up tremendously.

12 October 1912 Today was principally notable for the Grand Opera ... Stillwell played the organ. There were topical songs and old songs and ordinary language — Hoyle provided most of the fun.

15 October 1912 [CTM's birthday] The Doctor made a nice speech for Hoyle \& me, and we replied. I got rather sentimental in my reply, being somewhat touched. The evening closed with gramophone. 
17 October 1912 Mawson has divided up the MacKellar library - a few books each ... I would like to collar the hymn book, but don't like to ask for it.

18 October 1912 We invented a song between us, a copy of which is enclosed. We sang it very badly, which amused the crowd hugely. I was rather against The Sergeant of the Line, a gramophone tune, as I knew jolly well I was no good at the tune, but I depended on Dad, who got fearfully lost at times. We worked up in pitch at the rate of about an octave per verse \& had several changes of key to get it down again.

\section{Second year of expedition}

2 March 1913 Then dinner, after which I chained all my little four-footed friends up, and came in and put all the hymns on the gramophone.

4 March 1913 And light-hearted old Xavier too; the last thing I remember him saying was the last night I ever saw him. He came into my tent on the great lone plateau, from Mawson's, and I said — 'let's sing a song'; and it was 'studio auf ein Reis'.

27 March 1913 Tonight they asked me to 'sing' - no one else would - well, I could not possibly risk it. At last I give up. The joke lies in the reflection on the talent of the oufit.

8 August 1913 I have been playing the gramophone furiously, and doing my best for the spirits of the others.

One of Uncle's ${ }^{24}$ little diversions is to play hymns on the harmonium on Sunday afternoons, he can only manage one note, which he plays in bass and treble, we have him for the services, which are again regular. Mawson and I, vocalists of about the same calibre, usually sing a few extra ones during the afternoon.

Over the two seasons in Antarctica music gave the lives of people at the hut a diversity that complemented the somewhat dull daily routine. In recent years many of the expeditioners' diaries have been published. A close look into the music elements in these can give us important new clues to the environment they experienced — rich information for future research. 
This text is taken from Antarctica: Music, sounds and cultural connections, edited by Bernadette Hince, Rupert Summerson and Arnan Wiesel, published 2015 by ANU Press, The Australian National University, Canberra, Australia. 